\title{
Insulin Resistance in Patients with Chronic Hepatitis B Virus Infection: A Case-control Study
}

\section{Kronik Hepatit B Virüsü Enfeksiyonu Olan Hastalarda Insülin Direnci: Bir Olgu Kontrol Çalıșması}

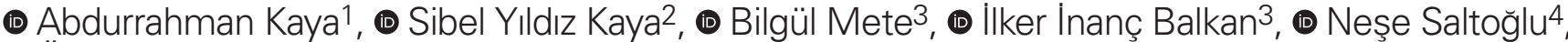 \\ (1) Ömer Fehmi Tabak4
}

1 University of Health Sciences Turkey, Istanbul Training and Research Hospital, Clinic of Infectious Disease, Istanbul, Turkey

${ }^{2}$ Çorum Sungurlu State Hospital, Clinic of Infectious Disease, Çorum Turkey

3/stanbul University-Cerrahpaşa, Cerrahpaşa Faculty of Medicine, Department of Medical Microbiolog, Istanbul, Turkey

\begin{abstract}
Objectives: It was aimed to compare the rate of insulin resistance $(\mathrm{IR})$ in patients with chronic hepatitis $\mathrm{B}$ virus $(\mathrm{CHB})$ infection with the general population.

Materials and Methods: The files of the patients were retrospectively examined. Patients testing for insulin and fasting blood glucose were included. For detecting IR, Homeostatic Model Assessment for Insulin Resistance (HOMA-IR) index was used. All patients were divided into 2 groups in terms of HOMA-IR. All data were compared between two groups. The rate of IR was compared with the general population.

Results: Forty-seven were female and the mean age was 38. Seventy-one had hepatitis $\mathrm{B}$ e antigen ( $\mathrm{HBeAg}$ )-negative $\mathrm{CHB}$ infection, 44 had $\mathrm{CHB}$ and 5 had HBeAg-positive $\mathrm{CHB}$ infection. IR was detected in 47 patients. The rates of IR were similar between females and males. The rates of IR was $38 \%$ in $\mathrm{HBeAg}$ negative $\mathrm{CHB}$ infection, $36.4 \%$ in $\mathrm{CHB}$ and $80 \%$ in $\mathrm{HBeAg}$ positive $\mathrm{CHB}$ infection. The rate of IR in patients with $\mathrm{CHB}$ infection was found to be $39 \%$ in our study.

Conclusion: This study showed higher rate of IR in patients with $\mathrm{CHB}$ infection than in the general population and thus these patients should be carefully monitored in terms of the occurrence of IR and diabetes mellitus.

Keywords: Insulin resistance, hepatitis B, metabolic syndrome
\end{abstract}

ÖZ

Amaç: Kronik hepatit B virüsü (KHB) enfeksiyonu olan hastalarda insülin direnci (IR) oranının genel popülasyonla karşılaştırıması amaçlanmaktadır.

Gereç ve Yöntemler: KHB enfeksiyonu olan hastaların dosyaları geriye dönük olarak incelendi. Çalışmaya insülin ve açlık kan şekeri düzeyleri ölçülen hastalar dahil edildi. IR'yi tespit etmek için Homeostatik Model Değerlendirmesi (HOMA-IR) indeksi kullanıldı. Tüm hastalar HOMA-IR açısından 2 gruba ayrıldı. Tüm veriler iki grup arasında karşılaştııılı. KHB enfeksiyonu olan hastalardaki IR oranı genel popülasyon ile karşılaştırıldı.

Bulgular: Hastaların 47'si kadındı ve ortalama yaş 38 (aralık: 2065) idi. Yetmiş bir hastada hepatit $B$ e antijeni ( $\mathrm{HBeAg}$ ) negatif $\mathrm{KHB}$ enfeksiyonu, 44'ünde $\mathrm{KHB}$ ve 5 'inde $\mathrm{HBeAg}$ pozitif $\mathrm{KHB}$ enfeksiyonu vardı. Kırk yedi hastada IR tespit edildi. IR oranları kadın ve erkek arasında benzerdi. IR oranları; HBeAg negatif $\mathrm{KHB}$ enfeksiyonu olanlarda \%38, KHB olanlarda \%36,4 ve HBeAg pozitif KHB enfeksiyonu olanlarda \%80 bulundu ve bunlar istatistiksel olarak anlamlı değildi. Çalışmamızda KHB enfeksiyonu olan hastalarda IR oranı \%39 olarak bulundu.

Sonuç: Bu çalışma, IR'nin KHB enfeksiyonu olan olgularda genel popülasyona göre daha yüksek oranlara sahip olduğunu ve bu nedenle bu hastalarda IR ve diabetes mellitus olușumunun dikkatle izlenmesi gerektiğini göstermiştir.

Anahtar Kelimeler: Insülin direnci, hepatit B, metabolik sendrom

Kaya A, Yıldız Kaya S, Mete B, Balkan II, Saltoğlu N, Tabak ÖF. Insulin Resistance in Patients with Chronic Hepatitis B Virus Infection: A Case-control Study. Viral Hepat J. 2021;27:89-92. 


\section{Introduction}

Metabolic syndrome (MS) is a cluster of conditions including central obesity, hypertension, glucose abnormality and dyslipidemia (1). It is associated with an increased risk of heart diseases, diabetes mellitus (DM) and the development of cancer (2). Though the pathogenesis of MS remains uncertain, insulin resistance (IR) has been considered a key mechanism (3). Also, IR is a main contributing factor of MS and DM.

Hepatitis B is one of the most common infection in the world and may cause complications including cirrhosis, liver failure and hepatocellular carcinoma (HCC) (4). Both hepatitis B and MS are common health problems. In general population, the prevalence of combined chronic hepatitis $\mathrm{B}$ (CHB) infection and MS is around $0.99 \%-1.74 \%(5,6,7)$. However, this rate varies depending on whether the area is endemic for HBV infection or MS. Furthermore, the coexistence of both diseases increases the risk of cirrhosis and HCC.

Recently, an experimental study showed that hepatitis B X protein impairs the hepatic insulin signaling pathway and that $\mathrm{CHB}$ infection is found to be related to IR (8). A clinical study also suggest that hyperinsulinemia develops in $\mathrm{CHB}$ infection and $\mathrm{CHC}$ virus $(\mathrm{CHC}$ ) infection (9). This association has been understood in $\mathrm{CHC}$ infection but the relationship between $\mathrm{CHB}$ infection and IR is still remained unclear $(10,11)$. In this study, the rate of IR in patients with $\mathrm{CHB}$ infection is compared with that in the general population.

\section{Materials and Methods}

This study was conducted between December 2016 and January 2018 in infectious diseases and clinical microbiology department. Of cases with $\mathrm{CHB}$ infection, the files of the patients were retrospectively examined. Since our study was a retrospective design, ethical approval and patient consent were not obtained. Patients testing for insulin and fasting blood glucose (FBG) were included. Their age, sex, height, body weight and body mass index (BMI), hepatitis B virus (HBV) DNA level, FBG, fibrosis score, hepatitis activity index (HAl), alanine aminotransferase, insulin level were determined. The height and weight of all patients were recorded and BMI was calculated. For detecting IR, Homeostatic Model Assessment for Insulin Resistance (HOMA-IR) index was calculated by using FBG and insulin values and "FBG $(\mathrm{mg} / \mathrm{dL}) X$ fasting insulin $(\mu \mathrm{U} / \mathrm{mL}) / 405$ " formula of 120 patients. All patients were divided into the 2 groups in terms of $I R ; 1)$ case group (HOMA-IR $\geq 2.5 \mathrm{mg} / \mathrm{dL}$ ) and 2) control group (HOMA-IR $<2.5 \mathrm{mg} /$ $\mathrm{dL})$. HBV infection was defined according to European Association for the Study of the Liver 2017 Clinical Practice Guidelines (12). Patients with known DM, cirrhosis and HCC were excluded from the study. All subjects were also negative for anti-hepatitis $C$ virus $(\mathrm{HCV})$, delta infection and human immunodeficiency virus. All data were compared between two groups. The rate of IR in the patients included in our study was compared with that in the general population.

\section{Statistical Analysis}

SPSS 21.0 program was used for all statistical analysis. Chisquare test was used for categorical data. Pearson's chi-square test results were accepted. In order to determine the presence of parametric data, normal distribution was examined by Kolmogrov-
Smirnov test. For data showing normal distribution, Student's t-test was used and $p<0.05$ was considered statistically significant.

\section{Results}

Of the 120 patients, 47 were female and the mean age was 38 (range: 20-65). Detailed characteristics of the patients shown in Table 1. Seventy-one had hepatitis B e antigen (HBeAg)-negative $\mathrm{CHB}$ infection, 44 had $\mathrm{CHB} ; 9$ patients had $\mathrm{HBeAg}$ positive and 25 patients were on anti-viral treatment) and only five had $\mathrm{HBeAg}$ positive $\mathrm{CHB}$ infection. IR was detected in 47 patients. The rates of IR were similar between female (38.4\%) and male $(40.4 \%)$. The rates of $\mathrm{IR} ; 38 \%$ in $\mathrm{HBeAg}$-negative $\mathrm{CHB}$ infection, $36.4 \%$ of $\mathrm{CHB}$ and $80 \%$ of patients in $\mathrm{HBeAg}$-positive $\mathrm{CHB}$ infection were found and these were not statistically significant. There was no statistically significant in IR according to the DNA levels of the patients. Five patients were weak (BMI: <18.5), 44 were normal weight (BMI: 18.5-24.9), 47 were overweight (BMI: 25-29.9) and 24 were obese $(\mathrm{BMI}>30)$. The rates of IR were $40 \%$ in weak patients, $25 \%$ in normal weight, $47 \%$ in overweight, and $50 \%$ in obese patients. The results were statistically significant between the groups. Of the 38 patients underwent biopsy, moderate-toadvanced fibrosis (F: 3-6) was detected in 8 patients and mild fibrosis ( $\mathrm{F}$ : $0-2$ ) was observed in the remaining 30 patients. $\mathrm{HAl}$ and fibrosis score were not statistically significant for IR. All statistical results were shown in Table 2 .

\section{Discussion}

$\mathrm{IR}$ is an important factor for MS and DM. CHC infection is well known to be associated with IR and increased risk of DM. In contrast, IR in CHB infection has not been clearly defined. Previous studies showed that IR in CHB infection was not different from healthy controls $(13,14)$. In 296 non-diabetic subjects, at the first health examination, the incidence of DM or glucose intolerance was found to be similar between HBV carriers and non-HBV controls,

\begin{tabular}{|l|l|}
\hline $\begin{array}{l}\text { Table 1.Detailed characteristics of the patients according to insuline } \\
\text { resistance }\end{array}$ \\
\hline Sex (female, $\mathrm{n})$ & 47 \\
\hline Age (year) & $38.96 \pm 11.57$ \\
\hline Body weight (kg) & $74.04 \pm 18.60$ \\
\hline Body height (cm) & $167 \pm 8.82$ \\
\hline Body mass index (kg/m $\left.{ }^{2}\right)$ & $26.47 \pm 6.26$ \\
\hline Hepatitis activity index & $5(1-12)$ \\
\hline Fibrosis score & $2(0-4)$ \\
\hline Alanine aminotransferase (U/L) & $38.30 \pm 20.10$ \\
\hline Fasting blood glucose (mg/dL) & $89.19 \pm 20.72$ \\
\hline Insulin level (mU/L) & $12.47 \pm 6.68$ \\
\hline HbA1C (\%) & $5.60 \pm 0.82$ \\
\hline HbeAg negativity (n) & 110 \\
\hline HOMA-IR & $2.96 \pm 2.16$ \\
\hline HBV-DNA level (IU/mL) & $57(0-1140000000)$ \\
\hline $\begin{array}{l}\text { HbA1C: Hemoglobin A1C, HbeAg: Hepatitis } \\
\text { Homeostatic Model Assessment for Insulin Resistance, HBV: Hepatitis B virus }\end{array}$ \\
\hline
\end{tabular}




\begin{tabular}{|c|c|c|c|}
\hline & HOMA-IR $\geq 2.5$ (47) & HOMA-IR <2.5 (73) & $\mathbf{p}$ \\
\hline Sex (Female) & 19 & 28 & 0.48 \\
\hline Body weight (kg) & $75.38 \pm 12.47$ & $73.13 \pm 22.22$ & 0.02 \\
\hline Body height $(\mathrm{cm})$ & $165.64 \pm 8.82$ & $168.51 \pm 8.94$ & 0.83 \\
\hline Fibrosis score & $2(0-4)$ & $2(0-4)$ & 0.76 \\
\hline Alanine aminotransferase (U/L) & $39.45 \pm 17.90$ & $37.50 \pm 22.03$ & 0.08 \\
\hline Fasting blood glucose (mg/dL) & $98.82 \pm 28.32$ & $82.56 \pm 9.92$ & 0.001 \\
\hline Insulin level (mU/L) & $18.47 \pm 6.80$ & $8.80 \pm 2.43$ & 0.001 \\
\hline
\end{tabular}

showing that asymptomatic $\mathrm{CHB}$ infection did not increase the risk of DM but unlike our study, IR was not investigated among the subjects (15). Contrary to relevant study comparing subjects with recovery from hepatitis $\mathrm{B}$ and $\mathrm{CHB}$ infection with those of diseasefree, a study showed that $\mathrm{CHB}$ infection was correlated with IR and has shown that patients with $\mathrm{CHB}$ infection may need to monitor the development of IR and DM (16). Also, in a systematic review examining chronic viral hepatitis and metabolic derangement, HCV infection is positively associated with IR and hepatic steatosis (17). In contrast, in this article, HBV infection is inversely associated with lipid metabolism, and exhibits no conclusive association with IR or the risk of DM. Taken together, the relationship between HBV and IR is uncertain (14).

Similar to our results, in a study from Turkey, no significant relationship was seen between IR and HBV-DNA levels and IR was observed more frequently in these patients compared to the general population (18). In a study from south Korea reviewing hepatitis B surface antigen (HBsAg) and anti-HCV Ab among study participants, unlike our study, IR was not evaluated, and it found that serologic evidence of HBV and HCV infection was associated with the prevalence of diabetes (19). Furthermore, Ye et al. (20) found $\mathrm{CHB}$ had a risk of developing $\mathrm{IR}$, especially higher in $\mathrm{CHB}$ patients with non-alcoholic fatty liver disease.

$\mathrm{IR}$ is defined as a subnormal biological response to normal insulin concentrations (21). It most frequently occurs in association with obesity, but can result from many causes including stress, medications, pregnancy. As consequences of obesity-related IR, it includes impaired glucose tolerance, impaired fasting glucose, type $2 \mathrm{DM}$, and increased insulin requirements in type $1 \mathrm{DM}$ (22). As expected, in this study, increased weight and BMI, high FBG, elevated insulin level and high hemoglobin A1C were found statistically significant for IR.

IR is seen in $25 \%$ of healthy population, $60 \%$ of those with impaired glucose tolerance and $60-75 \%$ of patients with type 2 DM (23). The rate of IR was found to be $39 \%$ in our study. This rate was slightly higher than the healthy population.

\section{Study Limitations}

The study has some limitations. It was a retrospective study and had low number of patients and some data were missing. Because this study was cross-sectional, it was difficult to conclude a causal relationship between HBV infection and IR. For valuable clinical data, this study may be generalized across Turkey.

\section{Conclusion}

This study showed IR has higher rate in cases with chronic HBV infection than in the general population and thus these patients should be carefully monitored the occurrence of IR and DM but further studies are needed to clarify this challenge.

\section{Ethics}

Ethics Committee Approval: Retrospective study.

Informed Consent: It was obtained.

Peer-review: Externally peer-reviewed.

\section{Authorship Contributions}

Concept: Ö.FT., Desing: B.M., I.I.B., Data Collection or Processing: S.Y.K., Analysis or Interpretation: N.S., Literature Search: A.K., Writing: A.K.

Conflict of Interest: No conflict of interest was declared by the authors.

Financial Disclosure: The financial support of the study was provided by the researchers.

\section{References}

1. Alberti KGMM, Zimmet P, Shaw J. Metabolic syndrome - A new world-wide definition. A consensus statement from the International Diabetes Federation. Diabet Med 2006;23:469-480.

2. Chen $\mathrm{CL}$, Yang HI, Yang WS, Liu CJ, Chen PJ, You SL, Wang LY, Sun CA, Lu SN, Chen DS, Chen CJ. Metabolic Factors and Risk of Hepatocellular Carcinoma by Chronic Hepatitis B/C Infection: A Follow-up Study in Taiwan. Gastroenterol 2008;135:111-121. 
3. Reaven GM. Banting Lecture 1988. Role of insulin resistance in human disease. Diabet1988;37:1595-1607.

4. McMahon BJ. Natural history of chronic hepatitis B. Clinics in liver disease. 2010;14:381-196.

5. Li WC, Lee YY, Chen IC, Sun C, Chiu FH, Chuang CH. Association between the hepatitis $B$ and $C$ viruses and metabolic diseases in patients stratified by age. Liver Int 2013;33:1194-1202.

6. Li X, Ren N, Ling $W$, Chen F, Zhang $W$, Fan $X$, Tian $M$, Zhang $T$, Li B, Pfeffer LM, Wu H, Zhang J. Adiponectin and its receptors in chronic hepatitis B patients with metabolic syndrome in China. Hepatogastroenterology 2012;59:1735-1743.

7. Wong VW, Wong GL, Chu WC, Chim AM, Ong A, Yeung DK, Yiu KK, Chu SH, Chan HY, Woo J, Chan FK, Chan HL. Hepatitis B virus infection and fatty liver in the general population. J Hepatol 2012;56:533-540

8. Kim K, Kim KH, Cheong J. Hepatitis B virus X protein impairs hepatic insulin signaling through degradation of IRS1 and induction of SOCS3. PloS One 2010;5:e8649.

9. Alizadeh AHM, Fallahian F, Alavian SM, Ranjbar M, Hedayati M, Rahimi F, Khedmat H, Etemadi A, Zali MR, Azizi F. Insulin resistance in chronic hepatitis B and C. Indian J Gastroenterol 2006;25:286-289

10. Narita R, Abe S, Kihara Y, Akiyama T, Tabaru A, Otsuki M. Insulin resistance and insulin secretion in chronic hepatitis $C$ virus infection. J Hepatol 2004;41:132-138.

11. Lecube A, Hernández C, Genescà J, Simó R. Proinflammatory cytokines, insulin resistance, and insulin secretion in chronic hepatitis C patients: A case-control study. Diabetes Care 2006;29:1096-1101.

12. European Association For The Study Of The Liver. EASL 2017 Clinical Practice Guidelines on the management of hepatitis B virus infection. J Hepatol 2017;67:370-398.

13. Wang CC, Hsu CS, Liu CJ, Kao JH, Chen DS. Association of chronic hepatitis B virus infection with insulin resistance and hepatic steatosis. J Gastroenterol Hepatol (Australia) 2008;23:779-782.
14. Wang CC, Tseng TC, Kao JH. Hepatitis B virus infection and metabolic syndrome: Fact or fiction? J Gastroenterol Hepatol (Australia) 2015;30:14-20.

15. Huang ZS, Huang TS, Wu TH, Chen MF, Hsu CS, Kao JH. Asymptomatic chronic hepatitis $B$ virus infection does not increase the risk of diabetes mellitus: A ten-year observation?. J Gastroenterol Hepatol (Australia) 2010;25:1420-1425.

16. Lee JG, Lee S, Kim YJ, Cho BM, Park JS, Kim HH, Cheong J, Jeong DW, Lee YH, Cho YH, Bae MJ, Choi EJ. Association of chronic viral hepatitis B with insulin resistance. World J Gastroenterol 2012;18:6120-6126.

17. Wang CC, Cheng PN and Kao JH. Systematic review: chronic viral hepatitis and metabolic derangement. Aliment Pharmacol Ther 2020;51:216-230

18. Senoymak MC and Ozkan H. Evaluation of the Relationship between Insulin Resistance and HBV DNA Level in Patients with HBeAg-negative Chronic HBV Infection (Natural Course Phase 3). Euroasian J Hepatogastroenterology 2020;10:85.

19. Hong $Y S$, Chang $Y$, Ryu S, Cainzos-Achirica M, Kwon MJ, Zhang Y, Choi Y, Ahn J, Rampal S, Zhao D, Pastor-Barriuso R, Lazo M, Shin $\mathrm{H}, \mathrm{Cho}, \mathrm{J}$ and Guallar E. Hepatitis B and $\mathrm{C}$ virus infection and diabetes mellitus: A cohort study. Scientific Rep 2017;7:4606.

20. Ye J, Hu X, Wu T, Wu Y, Shao C, Li F, Lin Y, Feng S, Wang W, Zhong B. Insulin resistance exhibits varied metabolic abnormalities in nonalcoholic fatty liver disease, chronic hepatitis B and the combination of the two: a cross-sectional study. Diabetol Metab Syndr 2019;11:1-13.

21. Epstein FH, Moller DE, Flier JS. Insulin resistance-mechanisms, syndromes, and implications. N Eng J Med 1991;325:938-948.

22. Semple RK, Savage DB, Cochran EK, Gorden P, O'Rahilly S. Genetic syndromes of severe insulin resistance. Endocr Rev 2011;32:498-514.

23. Hollenbeck C, Reaven GM. Variations in insulin-stimulated glucose uptake in healthy individuals with normal glucose tolerance. Clin Endocrinol Metab 1987;64:1169-1173. 